\title{
EXPERIMENTAL WORK FOR MECHANICAL PROPERTIES OF BRICK AND MASONRY PANEL
}

\author{
Saroj Phaiju ${ }^{1}$, Prachand Man Pradhan ${ }^{2}$ \\ ${ }^{1}$ Department of Civil Engineering, Khwopa Engineering College, Libali-8, Bhaktapur, Nepal \\ ${ }^{2}$ Department of Civil \& Geomatics Engineering, Kathmandu University, Dhulikhel, Nepal
}

\begin{abstract}
The use of Masonry panels in building construction has been popular in most of the parts of the world. However, the use of bricks and brick masonry in different parts of the world being of different nature in terms of quality, size, workmanship of construction, etc. It is yet a topic of interest to researchers to identify the mechanical properties, like Young's modulus of elasticity and shear modulus of brick masonry panels. It is essential to know the characteristic of brick masonry panels in order to evaluate the responses of masonry walls for any kind of loading. Individual bricks do possess better compressive capacity as compared to masonry walls. Masonry walls are bound together with either mud mortar or by cement sand mortars of various mixes as per the strength requirements. The essential strength properties in engineering are basically the compressive strength and the modulus of elasticity. The American Society for Testing and Materials (ASTM) standard is the most popular for testing bricks and brick masonry for these properties so far. Here, the study has been concentrated in finding the compressive strength of brick, mortar and brick masonry. The study is also done for Young's modulus of elasticity of brick as well as that of masonry wall. Similarly, the study is extended to find the modulus of rigidity of brick masonry panel. The study is done experimentally for the samples that are generally used in Kathmandu, Nepal. The samples include bricks, cement and sand particularly available in Kathmandu region.
\end{abstract}

Keywords: Masonry panel, Mechanical properties, Compressive strength, Modulus of elasticity, Shear modulus

\section{Introduction}

The value of mechanical properties; compressive strength, modulus of elasticity, shear modulus are required to analyze and design the masonry structures. Depending on the quality of materials, size, workmanship of construction, these values have wide range of adaptability. This research is focused on the finding of these values in local context.

Sahlin (1971) suggests that within practical limits, the wall strength is dependent on mortar strength as well as brick strength. Thus, the brick wall strength is about $25 \%$ to $50 \%$ of individual brick strength. The factors that affect the masonry strength according to Hilsdrof's theory include the uniaxial compressive strength of brick,

\footnotetext{
*Corresponding author: Saroj Phaiju

Department of Civil Engineering, Khwopa Engineering College, Libali-8, Bhaktapur, Nepal

Email: joras0816@gmail.com

(Received: Nov 5, 2017 Accepted: May 10, 2018)
}

biaxial tensile strength of brick, the failure criteria for a brick under a triaxial state of stresses, the uniaxial compression strength of mortar, behavior of mortar under triaxial loading and the coefficient of non-uniformities due to joints and brick properties. Thus, it is seen that there are many factors that affect the strength of brick masonry and as such various researchers have suggested the Young's modulus of elasticity of brick masonry in their own ways. The range of Young's modulus thus varies extremely. If $f_{b}$ is the compressive strength of individual brick, Glanville \& Barnett (1934) suggest that the Young's modulus of individual brick is $\mathrm{E}_{\mathrm{b}}=$ $300 * \mathrm{f}_{\mathrm{b}}$. Most of the empirical expressions suggested by various researchers fall within the range $E_{m}=$ $400 * f_{m}$ and $1000 * f_{m}$, where $f_{m}$ is the compressive strength of masonry panel and $E_{m}$ is the Young's modulus of elasticity of Masonry panel (Sahlin, 1971). Sahlin also suggests that the rough estimate of the modulus of elasticity of masonry in 
compression may be considered as $\mathrm{E}_{\mathrm{m}}=700 * \mathrm{f}_{\mathrm{m}}$.

As per FEMA273 the masonry compressive strength may be taken as at the most 900psi for masonry in good condition, 600psi for masonry in fair condition and 300 psi for masonry in poor condition. It is also suggested that the Young's modulus of elasticity of masonry wall may be considered as $\mathrm{E}_{\mathrm{m}}=550 * \mathrm{f}_{\mathrm{m}}$.

Pauley \& Priestley (1992) uses $\mathrm{E}_{\mathrm{m}}=600 * \mathrm{f}_{\mathrm{m}}$ where $\mathrm{f}_{\mathrm{m}}$ is compressive strength of masonry (in MPa or psi). Pradhan, 2012 has used $\mathrm{fm}$ as $5.6 \mathrm{~N} / \mathrm{mm}^{2}$ and the Young's modulus as $2750 \mathrm{~N} / \mathrm{mm}^{2}$ his study which further indicate that the relation chosen approximately as $\mathrm{E}_{\mathrm{m}}=490 * \mathrm{f}_{\mathrm{m}}$.

Rodrigues, Varum, \& H. Coasta (2010) have tested experimentally for bricks, mortar joints and panels for Young's modulus as well as for Shear modulus and suggested the values for them. Brick's compressive strength perpendicular to the bed joints is $2.8 \mathrm{~N} / \mathrm{mm}^{2}$. Similarly, the mortar joints tensile strength is $0.59 \mathrm{~N} / \mathrm{mm}^{2}$, while compressive strength is $1.33 \mathrm{~N} / \mathrm{mm}^{2}$. Their results for masonry wall compressive strength is $1.1 \mathrm{~N} / \mathrm{mm}^{2}$. The Young's modulus of masonry wallets perpendicular to the bed joints is given as $1.873 \mathrm{GPa}\left(1873 \mathrm{~N} / \mathrm{mm}^{2}\right)$. The shear modulus is given as $0.657 \mathrm{GPa}\left(657 \mathrm{~N} / \mathrm{mm}^{2}\right)$.

Bergami (2007) has done experimentation for mechanical properties of masonry panels. According to him, the Young's modulus of infilled masonry is 3939.41 MPa and shear modulus of half full brick infilled masonry wall is $2643.43 \mathrm{MPa}$.

Eurocode 06 prescribes the empirical relation for shear modulus of rigidity of brick panel as $\mathrm{G}=0.4$ $\mathrm{E}_{\mathrm{m}}$. This shows that the shear modulus is about $40 \%$ that of Young's modulus of masonry panel.

\section{Experimental Set-up}

The test specimens chosen were red colored, metallic ringing sound, hand-made chimney kiln burnt clay bricks that are generally available and used in Kathmandu valley. Similarly, the ordinary portland cement and sand which are usually available in the market are taken for testing purpose. The structural testing laboratory of Khwopa Engineering College which houses Universal Testing Machine (UTM) of 40 Tonne capacity was used for loading purpose. Dial gauges of least count $0.01 \mathrm{~mm}$ were used for deflection measurement. The loads and sizes of panels needed to be conveniently handled within the UTM, thus the specimens were scaled down to $1: 3$. The sand and brick samples were accordingly scaled down; even the mortar thickness was also scaled down correspondingly.

Table 1. Physical characteristics of prototype samples

\begin{tabular}{|c|c|c|c|c|c|}
\hline S.N & Items & properties & Length $(\mathbf{m m})$ & Breath $(\mathbf{m m})$ & Depth $(\mathbf{m m})$ \\
\hline 1 & Brick & First class & 230 & 110 & 50 \\
\hline 2 & Sand & $4.75 \mathrm{~mm}$ sieve passed & & & \\
\hline 3 & O.P.C & 53 grade & & & 1200 \\
\hline 4 & Brick panels & density $17 \mathrm{KN} / \mathrm{m}^{3}$ & 1200 & 230 & 12 \\
\hline 5 & Mortar & Mix $1: 4$ & & & \\
\hline
\end{tabular}

Table 2. Scaled down model data

\begin{tabular}{|c|c|c|c|c|c|}
\hline SN & Items & properties & Length $(\mathbf{m m})$ & Breath (mm) & Depth (mm) \\
\hline 1 & Brick & First class & 77 & 34 & 17 \\
\hline 2 & Sand & $2 \mathrm{~mm}$ sieve passed & & & \\
\hline 3 & O.P.C & 53 grade & & & \\
\hline 4 & Brick panels & density $17.3 \mathrm{KN} / \mathrm{m}^{3}$ & 400 & 77 & 400 \\
\hline 5 & Mortar & Mix $1: 4$ & & & 4 \\
\hline
\end{tabular}




\subsection{Brick Compression Test}

The prototype brick sample and Scaled down brick samples were of sizes $230 \mathrm{~mm} \times 110 \mathrm{~mm}$ x $50 \mathrm{~mm}$ and $77 \mathrm{~mm} \quad \mathrm{x} 34 \mathrm{~mm} \quad \mathrm{x} 17 \mathrm{~mm}$ respectively. The brick compression test was performed as per the ASTM standards. Total of seven samples were tested with the UTM. The force application was very slow at the speed of $14 \mathrm{~N} / \mathrm{mm}^{2}$ so that the displacement of brick on load increment could be easily measured. The force-deflection curve were plotted in order to identify the Young's modulus and the compressive strength of individual brick.

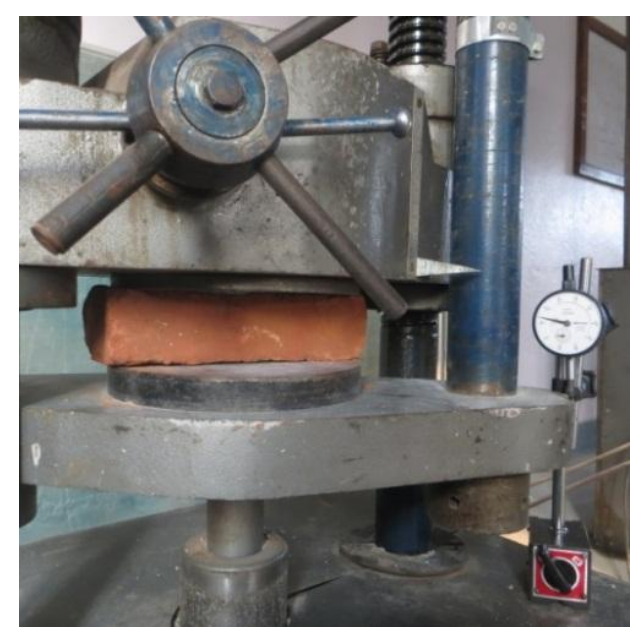

Fig. 1 Brick compression test

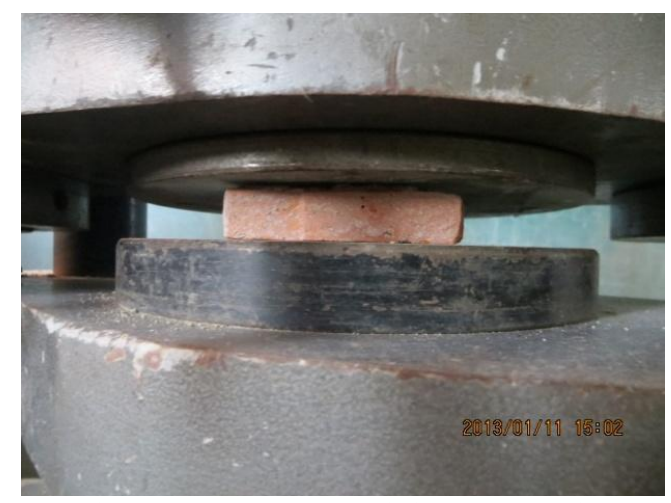

Fig. 2 Scale down Brick compression test

\subsection{Mortar Testing}

The sand sample available was sieved in order to achieve the 1:3 scaled down requirements. Then the cement sand mix of 1:4 was used to prepare mortar test sample cube as per the Indian standards. The cubes of size $100 \mathrm{~mm} \times 100 \mathrm{~mm} \times 100 \mathrm{~mm}$ after curing for 28 days were tested under UTM for cube strength.

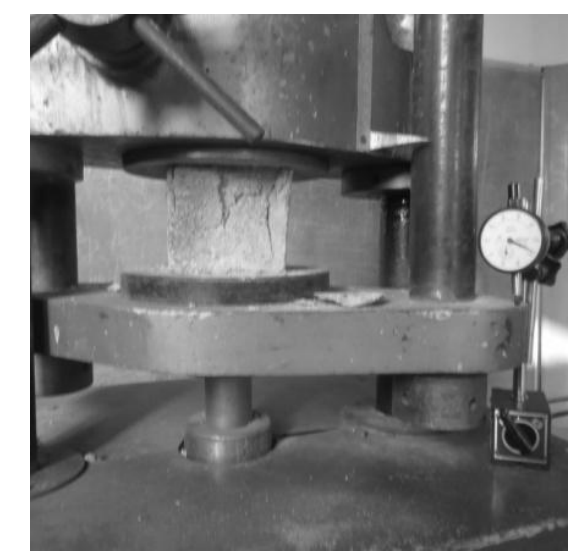

Fig. 3 Cement sand mortar cube test

\subsection{Brick Masonry Compression Test}

Three brick panels of dimensions as per Table 2 with mortar thickness $4 \mathrm{~mm}$ have been tested under UTM with very slow application of loading increment. A dial gauge was used to measure the displacement as the compressive force was applied to the brick panel as shown in Fig 4. The forcedisplacement curve was plotted to identify the Young's modulus as well as the compressive strength of brick panel. The force required for initial crack, and also the crack pattern was studied as the loading increased. In order to apply the loads uniformly, two supporting beams of mild steel were prepared as shown in Fig 5. The panels were installed between the beams.

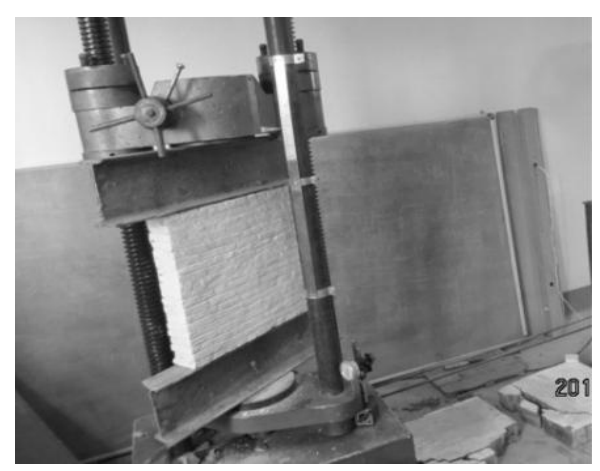

Fig. 4 Compression test of brick masonry

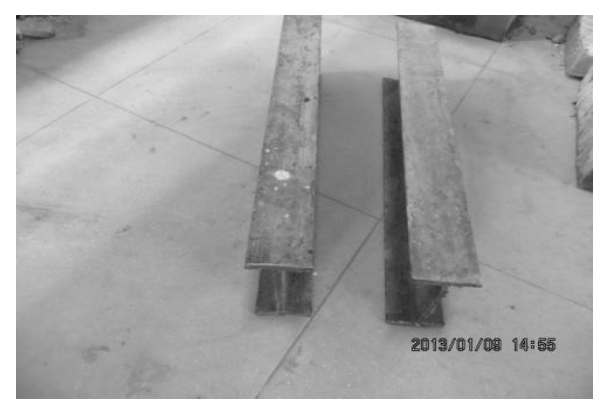

Fig. 5 Supporting beams 


\subsection{Brick Masonry Shear Test}

Three brick masonry panels of the size as per Table 2 were applied loadings as shown in the Fig 6 . The application of loading was very slow at the speed rate of $14 \mathrm{MPa}$ per minute, so that the deflection of panels at two locations was conveniently observed. The displacement of the panel both vertically as well as horizontally were measured with the support of dial gauges of $0.01 \mathrm{~mm}$ sensitivity. The displacement as well as crack propagation phenomena and also the crack patterns were studied. In order to apply the loads, two supporting saddles of mild steel were prepared as shown in Fig 7. The panels were installed within the saddles.

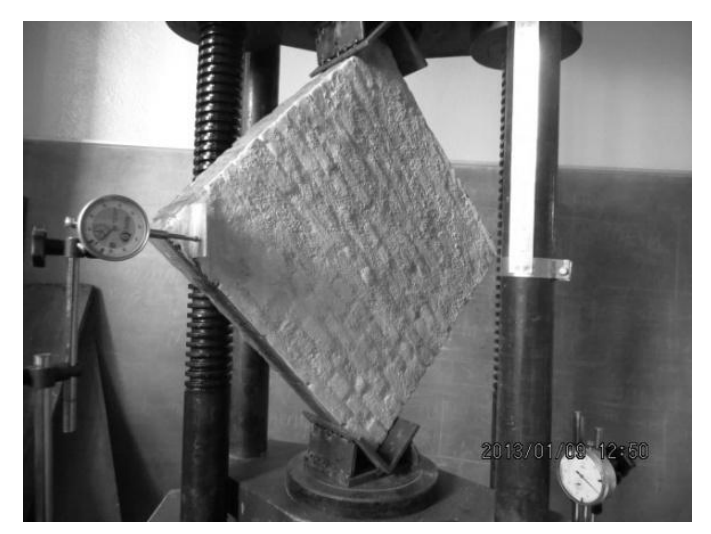

Fig. 6 Shear testing

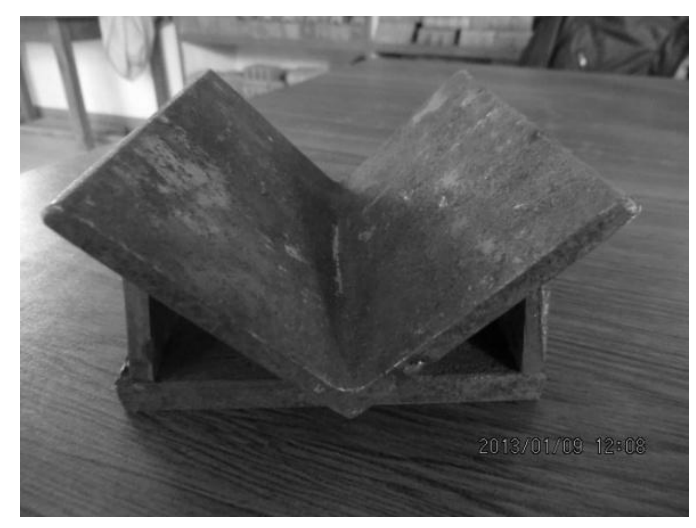

Fig. 7 Supporting Saddles

\section{Results and Discussions}

\subsection{Brick, Mortar and Brick Masonry Compression Tests}

The test results for brick compression suggest that the full brick samples chosen had the compression strength of $11.12 \mathrm{~N} / \mathrm{mm}^{2}$ and that of scaled down brick had $13.73 \mathrm{~N} / \mathrm{mm}^{2}$, and the compression strength of masonry panel is $2.5 \mathrm{~N} / \mathrm{mm}^{2}$. The tests of mortar cube suggests that the motar samples had compressive strength of $3.8 \mathrm{~N} / \mathrm{mm}^{2}$. This informs us that the masonry panel would acquire about $23 \%$ strength of individual brick. This indicates that the brick panel that is constructed in Kathmandu has the strength within the range prescribed by international standards as compared to the documents suggested by Sahlin.

\subsection{Young's Modulus of Elasticity of Brick and Masonry Panels}

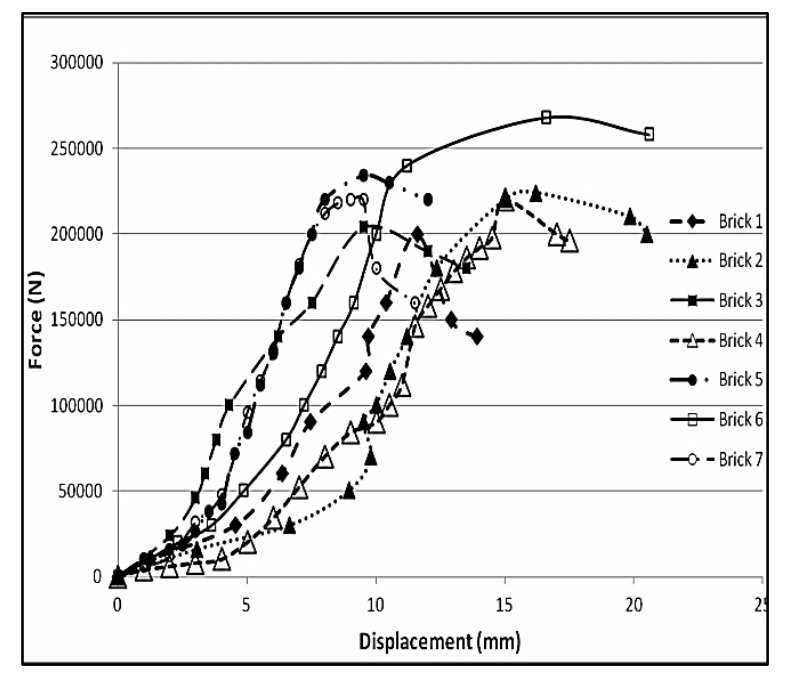

strength of $11.12 \mathrm{~N} / \mathrm{mm}^{2}$ and that of scaled down brick had $13.73 \mathrm{~N} / \mathrm{mm}^{2}$, and compression strength of Masonry Panel is $2.5 \mathrm{~N} / \mathrm{mm}^{2}$. The test of mortar Fig. 8 Compression force versus axial displacement of bricks

The Young's modulus of masonry panel observed from the experiment suggests that the value is about $2700 \mathrm{~N} / \mathrm{mm}^{2}$. Here, the Young's modulus of masonry panel observed as $E_{m}=1085 * f_{m}$, where $f_{m}$ is compressive strength of individual brick. The initial crack was used to identify the Elastic limit from which the Young's modulus of elasticity was identified. After the initial crack, the masonry panel could accept significant force beyond the elastic limits. The complete failure occurred at the force value of $72 \mathrm{KN}$ and elastic limit force value is 7 $\mathrm{KN}$, which was $9.7 \%$ of the complete failure force. 


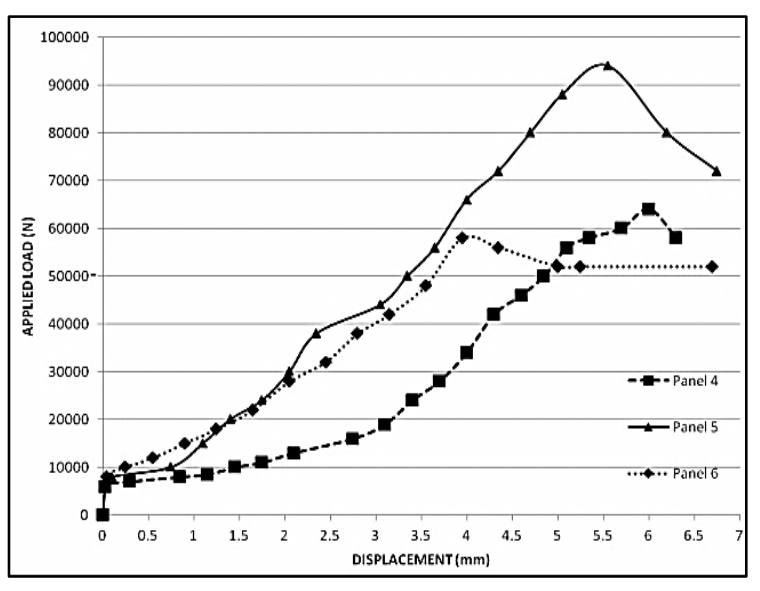

Fig. 9 Compression force versus axial displacement of masonry panel

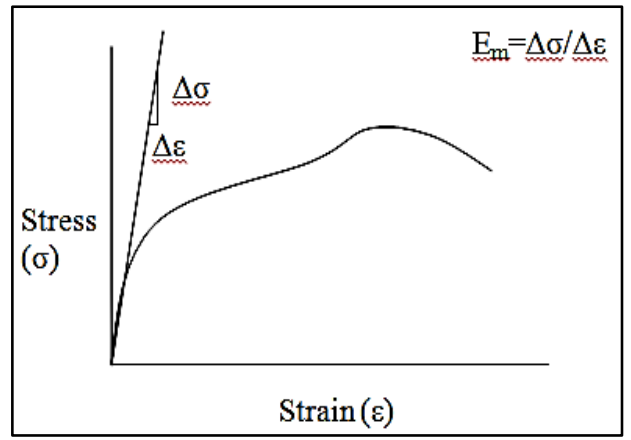

Fig. 10 Graphical representation for Tangent modulus, $\mathrm{E}_{\mathrm{m}}$

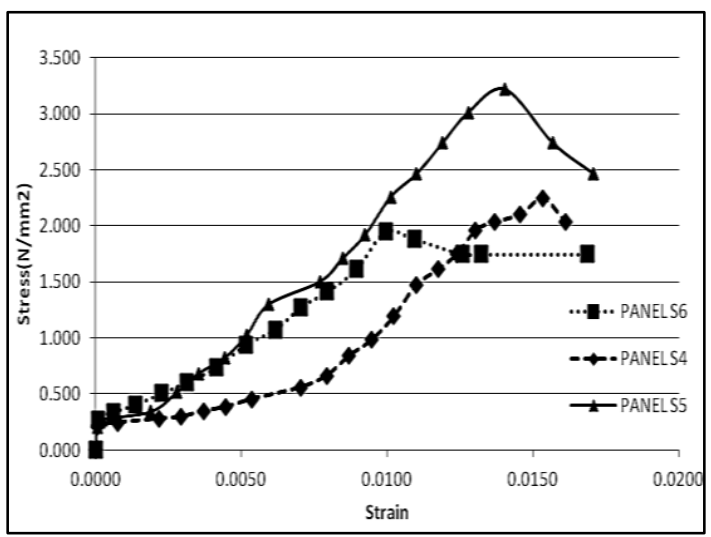

Fig. 11 Stress-Strain curve of Panels

\subsection{Shear Modulus of Rigidity of Masonry Panels}

The shear test result showed that the modulus of rigidity of brick panel can be estimated as 915 $\mathrm{N} / \mathrm{mm}^{2}$, which is about $34 \%$ of the Young's modulus of elasticity. This further suggests that an empirical relation between Shear modulus and Young's modulus can be established. The relation may be taken as $\mathrm{G}=0.34 * \mathrm{E}_{\mathrm{m}}$ which is slightly less than that prescribed by the Eurocode 06. The failure pattern was observed as to propagate from the sides as shown in the Fig. 12. The failure pattern indicated that the panels would crack or fail mainly by shear or slipping action within the mortar joints. The loading was applied till the panel completely failed.

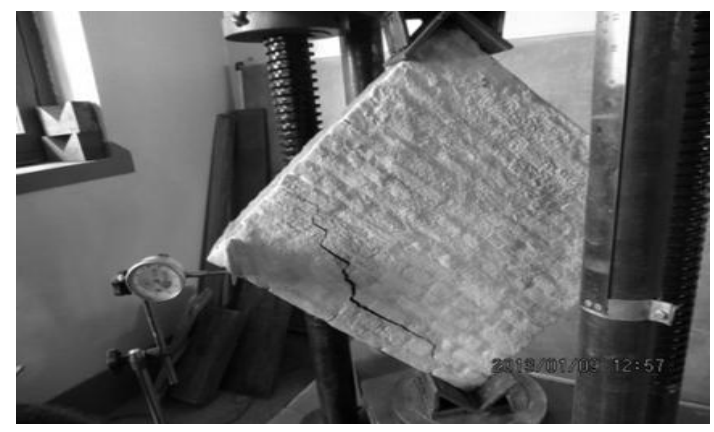

Fig. 12 Propagation of cracks
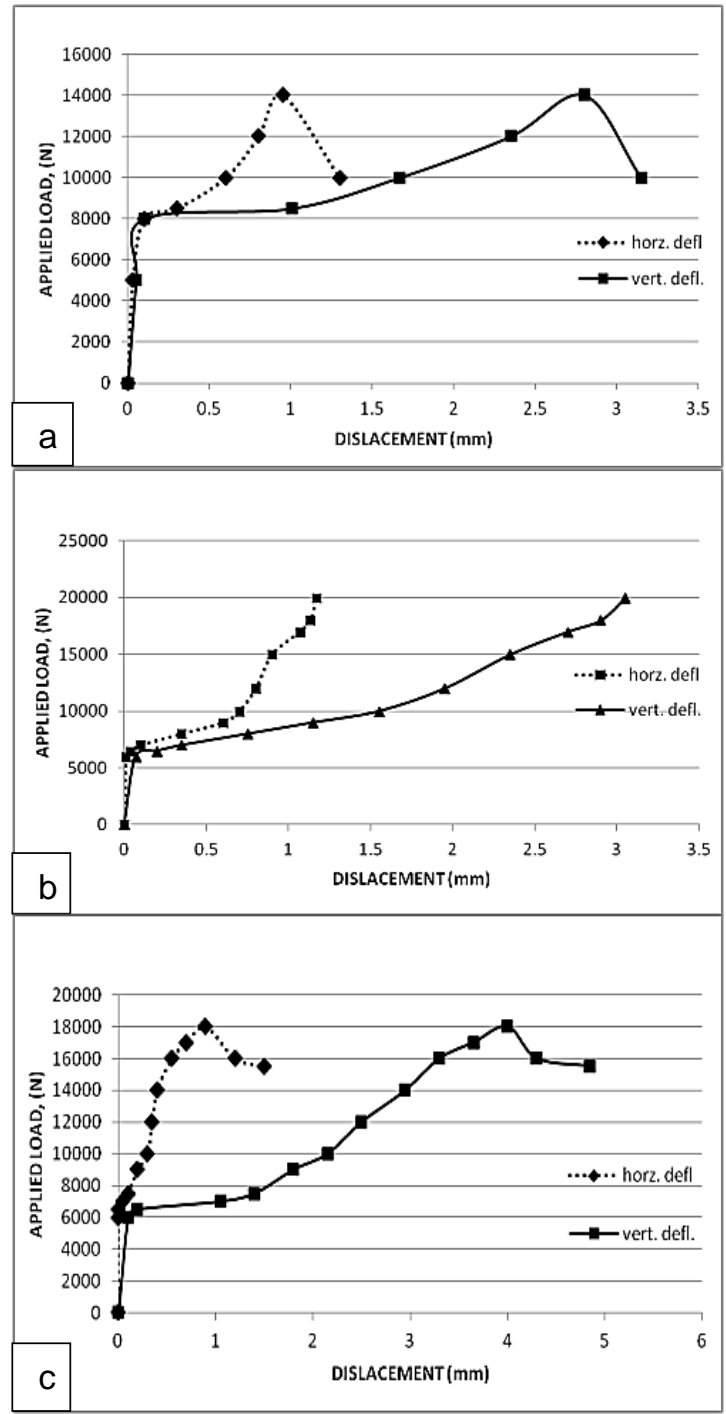

Fig. 13 Load displacement curves (horizontal and vertical ) 
Table 3. Mechanical properties of cement mortar, bricks and masonry

\begin{tabular}{|c|c|c|c|}
\hline S.N & Item & Parameters & values \\
\hline \multirow{2}{*}{1} & \multirow{2}{*}{ Cement mortar } & Compressive strength $\left(\mathrm{f}_{\mathrm{cm}}\right)$ & $3.8 \mathrm{~N} / \mathrm{mm}^{2}$ \\
\hline & & Young's modulus $\left(\mathrm{E}_{\mathrm{cm}}\right)$ & $2555.5 \mathrm{~N} / \mathrm{mm}^{2}$ \\
\hline \multirow{2}{*}{2} & \multirow{2}{*}{ Bricks } & Compressive strength $\left(\mathrm{f}_{\mathrm{b}}\right)$ & $11.12 \mathrm{~N} / \mathrm{mm}^{2}$ \\
\hline & & Young's modulus $\left(\mathrm{E}_{\mathrm{b}}\right)$ & $3357.9 \mathrm{~N} / \mathrm{mm}^{2}$ \\
\hline \multirow{6}{*}{3} & \multirow{6}{*}{ Masonry } & Compressive strength $\left(\mathrm{f}_{\mathrm{m}}\right)$ & $2.5 \mathrm{~N} / \mathrm{mm}^{2}$ \\
\hline & & Young's modulus $\left(\mathrm{E}_{\mathrm{m}}\right)$ & $2703.2 \mathrm{~N} / \mathrm{mm}^{2}$ \\
\hline & & Shear modulus $(\mathrm{G})$ & $915.1 \mathrm{~N} / \mathrm{mm}^{2}$ \\
\hline & & Poisson's ratio $(v)$ & 0.32 \\
\hline & & \multicolumn{2}{|c|}{$\mathrm{G}=0.34 \mathrm{E}_{\mathrm{m}}$} \\
\hline & & \multicolumn{2}{|c|}{$\mathrm{E}_{\mathrm{m}}=1085 \mathrm{f}_{\mathrm{m}}$} \\
\hline
\end{tabular}

\subsection{Poison's Ratio of Masonry Panel}

It was observed from the force displacement data that the longitudinal and transverse strains were obtained which is further used to compute the Poisson's ratio of the masonry panels. Thus, from the experimental work, the Poisson's ratio for masonry panel is found to be 0.32 , which is slightly more than that of concrete's value.

\section{Conclusions and Recommendations}

The conclusion from the study is that the mechanical properties of locally available handmade bricks of Kathmandu may be considered to have Young's modulus of elasticity as $2700 \mathrm{~N} / \mathrm{mm}^{2}$, and the Shear modulus may be considered as $34 \%$ of Young's modulus of masonry wall. The mortar of $1: 4$ cement sand mix may be considered to have compressive strength as $3.8 \mathrm{~N} / \mathrm{mm}^{2}$. The individual brick may be considered to have compressive strength as 11.12 $\mathrm{N} / \mathrm{mm}^{2}$ and that of the brick masonry may be considered to have $2.5 \mathrm{~N} / \mathrm{mm}^{2}$. This compressive strength of brick masonry according to FEMA273 indicates that the brick masonry is of poor quality. Thus, we have to increase the strength of brick masonry in order to meet the FEMA standards of at least fair condition.
This further indicates that the Young's modulus of elasticity as well as Shear modulus of rigidity needs to be improved. The handmade bricks have been found to have density of $17 \mathrm{KN} / \mathrm{m}^{3}$ in dry state, which also indicates that the strength of brick masonry might have been less due to less compaction being applied during moulding work. If the bricks were allowed to compact properly during its manufacturing, the density could have increased, which would further be the reason for strength enhancement.

However, since there are many factors which affect the strength and quality of brick masonry, the compact brick is just one recommendation for improving the masonry's strength. Besides, as other researchers indicate, the workmanship and mortar strength are very crucial factors for strength quantification.

\section{References}

[1] ASTM E 519:07 - Standard Test Method for Diagonal Tension (Shear) in Masonry Assemblages

[2] Bergami, A. V. (2007). Implementation and experimental verification of models for nonlinear analysis of masonry infilled r.c. frames. Rome, Italy: Universita degli studi ROMA TRE. 
[3] Eurocode 06: Design of Masonry Structure, Part 1-1, General Rules for Reinforced and Unreinforced Masonry Structures

[4] FEMA273. Siesmic Rehabitation Guidelines. USA

[5] Glanville, \& Barnett. (1934). Mechanical Properties of Bricks and Brickwork Masonry. Garston, Watford, Herts, Her Majesty's Stationery Office, London: Department of Scientific and Industrial Research, Building Research, Special Report No.22, Building Researach Station.

[6] Hilsdorf, H. (1969). "An Investigation into the Failure Mechanism of Brick Masonry Loaded in Axial Compression", Designing, Engineering and Construction with Masonry Products, edited by Dr. Franklin Johnson. Texas: Gulf Publishing Company.

[7] IS: 3495(Part 1)- 1992, Indian Standard, Methods of Tests of Burnt Clay Building Bricks

[8] IS:1905- 1987, Indian Standard, code of Practice for Structural Use of Unreinforced Masonry

[9] IS: 2250- 1981, Indian Standard, code of Practice forPreparation and Use of Masonry Mortats

[10] IS : 2116 - 1980, Indian Standard, Specification for Sand and Masonry Mortars

[11] Paulay, T., \& Priestley, M. (1992). Seismic Design of Reinforced Concrete And Masonry Buildings. USA: John Wiley \& Sons.

[12] Pradhan, P. (2012). Equivalent Strut Width for Partial Infilled Frames. Journal of Civil Engineering Research , 42-48.

[13] Rodrigues, Varum, \& H. Costa, A. (2010). Simplified Macro-Model for Infill Masonry Panels. Journal of Earthquake Engineering, Taylor \& Francis , 390-416

[14] Sahlin, S. (1971). Structural Masonry. New Jersey: Prentice Hal 